\title{
PEMANFAATAN MEDIA KOMPUTERISASI DALAM PEMBELAJARAN AKTIF, INOVATIF, EFEKTIF, DAN MENYENANGKAN DI SD NEGERI 023 SAMARINDA UTARA
}

\author{
Hani Subakti ${ }^{1}$ \\ ${ }^{*}$ Universitas Widya Gama Mahakam Samarinda \\ *hanisubakti@uwgm.ac.id
}

\begin{abstract}
Utilization of learning through computerized media is still a problem for some elementary schools in Samarinda City. This is based on the unavailability of a computer practice laboratory that can be used by educators or students. In fact, if computerized media is available, it is signaled that it can increase the knowledge and achievement of students. In addition, active, innovative, effective, and fun learning (PAIKEM) can help make the teaching and learning process more interesting. Thus, when computerized facilities are introduced, it is hoped that they will be able to contribute knowledge to students which will lead to an increase in student knowledge. The purpose of this community service is to socialize the use of computerized media in active, innovative, effective, and fun learning (PAIKEM). The community service method is carried out in the form of socialization to students at SD Negeri 023 North Samarinda about the use of computerized media in active, innovative, effective, and fun learning (PAIKEM).
\end{abstract}

Keywords: Computerized media, PAIKEM

\begin{abstract}
Abstrak
Pemanfaat pembelajaran melalui media komputerisasi masih menjadi permasalahan bagi sebagian sekolah dasar yang ada di Kota Samarinda. Hal ini didasari tidak tersedianya laboratorium praktik komputer yang dapat digunakan oleh pendidik ataupun perserta didik. Padahal bila media komputerisasi telah tersedia disinyalisasi dapat meningkatkan pengetahuan dan prestasi peserta didik. Selain itu pula pembelajaran yang aktif, inovatif, efektif, dan menyenangkan (PAIKEM) dapat membantu proses belajar mengajar semakin menarik. Dengan demikian bila sarana komputerisasi diperkenalkan nantinya diharapkan mampu memberikan sumbangsih pengetahuan bagi para siswa yang akan bermuara pada peningkatan pengetahuan siswa. Tujuan pengabdian kepada masyarakat ini adalah untuk menyosialisasikan pemanfaatan media komputerisasi dalam pembelajaran yang aktif, inovatif, efektif, dan menyenangkan (PAIKEM). Metode pengabdian kepada masyarakat dilaksanakan dalam bentuk sosialisasi kepada para siswa di SD Negeri 023 Samarinda Utara tentang pemanfatan media komputerisasi dalam pembelajaran yang aktif, inovatif, efektif, dan menyenangkan (PAIKEM).
\end{abstract}

Kata Kunci: Media komputerisasi, PAIKEM

\section{PENDAHULUAN}

Di zaman yang sudah serba modern ini masih saja ditemukan sekolah dasar di Kota Samarinda yang belum memiliki sarana dan prasarana seperti laboratorium komputer. Hal ini mengakibatkan peserta didik kurang memahami penggunaan komputer untuk proses belajar mereka. Di sisi lain komuterisasi kini telah menjadi sarana tak terpisahkan dari kehidupan manusia yang hidup di dunia. Untuk itu diperlukan pemahaman terhadap media komputerisasi yang mampu menyambungkan sebuah sistem pembelajaran terkini agar lebih mudah dipahami. 
Sekali tiga uang media komputerisasi juga disinyalisasi mampu meningkatkan ketertarikan terhadap pembelajaran di sekolah. Ini terlihat dari rasa ingin tahu yang tinggi bagi siswa sekolah dasar. Atas dasar itu pembelajaran yang aktif, inovatif, efektif, dan menyenangkan (PAIKEM) dapat dijalankan.

Penggabungan media komputerisasi dan pembelajaran yang aktif, inovatif, efektif, dan menyenangkan (PAIKEM) diharapkan mampu memberikan pemahaman yang langsung berdampak pada peserta didik di sekolah. Untuk ini semua diperlukan sinergi dari semua pihak agar mampu berkolaborasi bagi peningkatan dan pemahaman peserta didik. Salah satu cara yang paling tepat adalah dengan mengajarkan pembelajaran dengan menggunakan media komputerisasi yang menarik minat peserta didik.

Di sisi lain pembelajaran yang aktif, inovatif, efektif, dan menyenangkan (PAIKEM) dapat menjadi tolok ukur kedua dalam proses pembelajaran di kelas. Ini dapat terlihat dari antusias peserta didik di dalam kelas. Untuk itu diperlukan kerja ekstra dalam memberikan pemahaman langsung kepada peserta didik.

Dengan singkronisasi antara media komputerisasi dan penerapan pembelajaran yang aktif, inovatif, efektif, dan menyenangkan (PAIKEM) diharapkan mampu meningkatkan prestasi dan pengetahuan siswa. Jika ini semua dapat sesuai dengan rencana maka bisa dipastikan peserta didik mendapatkan pemahaman yang lebih mengenai belajar melalui media komputerisasi. Kemudian peserta didik juga akan ikut merasakan sensasi pembelajaran yang aktif, inovatif, efektif, dan menyenangkan (PAIKEM) bagi diri sendiri dan teman-temannya di kelas.

\section{Permasalahan Mitra}

Terjadi permasalahan pada mitra pengabdian masyarakat yaitu tidak tersedianya laboratorium komputer atau media komputer di SD Negeri 023 Samarinda Utara. Hal ini menyulitkan peserta didik dalam proses belajar siswa. Untuk memberi pemahaman kepada peserta didik harus dilakukan dengan cara melihat media komputerisasi itu secara langsung hingga pembelajaran yang aktif, inovatif, efektif, dan menyenangkan (PAIKEM) dapat berjalan dengan baik.

\section{Solusi Permasalahan}

Media komputerisasi dan pembelajaran yang aktif, inovatif, efektif, dan menyenangkan (PAIKEM) dapat menjadi salah satu pilihan untuk meningkatkan pemahaman kepada peserta didik. Pembelajaran yang aktif, inovatif, efektif, dan menyenangkan (PAIKEM) itu sendiri mampu mendongkrak kreativitas para peserta didik di dalam kelas. Jadi ketika media komputerisasi disandingkan dengan pembelajaran yang aktif, inovatif, efektif, dan menyenangkan (PAIKEM) diharapkan mampu membersamai dan menghasilakan sinergitas yang baik.

\section{Tujuan Pengabdian kepada Masyarakat}

Tujuan pengabdian kepada masyarakat kali ini adalah untuk menyosialisasikan pemanfaatan media komputerisasi pada peserta didik dengan harapan akan menghadirkan pembelajaran yang aktif, inovatif, efektif, dan menyenangkan (PAIKEM) di SD Negeri 023 Samarinda Utara, Kota Samarinda.

\section{Luaran (Output)}

Luaran dari pengabdian kepada masyarakat ini adalah publikasi pada jurnal. Selain itu pengabdian masyarakat di SD Negeri 023 Samarinda Utara Kota Samarinda diharapkan dapat menjadi masukan bagi sekolah untuk dapat menganggarkan pembelian komputer melalui dana bantuan operasional sekolah nasional (BOSNAS). Hal ini diharapkan akan mampu memberikan keluaran bagi peserta didik dalam belajar melalui media komputerisasi dengan menghadirkan pembelajaran yang aktif, inovatif, efektif, dan menyenangkan (PAIKEM) di dalam kelas. 


\section{METODE PELAKSANAAN}

\section{Media Komputerisasi}

Hal yang pertama dan paling utama yang harus dilakukan adalah memahami atau menelaah dari pengertian komputerisasi. Sebelum lahirnya komputer, kita selalu mengolah suatu data atau pekerjaan dengan cara manual, dari sinilah munculnya era yang disebut dengan komputerisasi. Sampai saat ini di dunia hampir semua bidang pekerjaan sudah menggunakan akses sistem komputerisasi sebagai solusi dalam mempermudah suatu pekerjaan serta meningkatkan kualitas kerja.

Diperlukan juga sumber daya manusia dalam hal ini peserta didik dengan pemahaman yang tinggi, khususnya di dalam hal memahami ataupun untuk pemanfaatan sistem komputerisasi yang sudah diterapkan sebelumnya. Perlu digarisbawahi bahwa hal yang tidak pernah lepas dari kata komputerisasi yakni komputer itu sendiri, jadi definisi dari komputerisasi yakni suatu alat atau perangkat elektronika yang di mana dapat digunakan dalam proses pembelajaran dengan cepat dan akurat. Sedangkan pengertian dari Komputerisasi adalah suatu perubahan mekanisme pengolahan data yang sebelumnya masih bersifat manual menjadi otomatis karena hal itu menggunakan media komputer. Kalau fungsi dari komputerisasi ini sendiri yaitu sebagai alat bantu manusia dalam mengerjakan suatu pekerjaan kantor maupun sekolah dengan pengetahuan yang cukup untuk menggunakan media komputer.

\section{Manfaat Komputerisasi}

Manfaat dari komputerisasi yakni untuk menggantikan segala kegiatan yang bersifat manual menjadi memudahkan penggunanya dalam mengerjakan suatu tugas baik itu proses pembelajaran di sekolah, tugas siswa di rumah, dan masih banyak lagi. Sebagai contohnya manfaat dari komputerisasi ini dalam bidang pendidikan seperti penggunaan komputer untuk menyajikan pembelajaran lebih menarik melalui visual atau gambar yang dimunculkan. Disaat bersamaan peserta didik akan terpacu untuk memperhatikan Bapak/Ibu guru dalam menjelaskan pelajaran di depan kelas. Dengan adanya gambar, suara, grafik, dan lain-lain dapat menstimulus peserta didik hingga menyerap pembelajaran.

\section{Konsep PAIKEM}

Pendekatan PAIKEM adalah sebuah strategi dan terobosan pembelajaran yang memungkinkan peserta didik untuk mengerjakan kegiatan yang beragam dalam rangka mengembangkan keterampilan dan pemahamannya. Ini semua dapat terjadi dengan penekanan peserta didik belajar sambil bekerja. Sementara itu guru menggunakan berbagai sumber dan alat bantu belajar, supaya pembelajaran lebih menarik, menyenangkan dan efektif.

Pendekatan PAIKEM sebagai sebuah strategi pembelajaran, memiliki 5 (lima) kriteria yang dapat diuraikan sebagai berikut:

\section{Pembelajaran Aktif}

Belajar aktif adalah salah satu cara untuk mengikat informasi yang baru kemudian menyimpannya dalam otak. Hal ini perlu dilakukan karena salah satu faktor yang menyebabkan informasi cepat dilupakan adalah faktor kelemahan otak manusia itu sendiri. Pembelajaran Aktif adalah bahwa dalam pembelajaran peserta didik aktif secara fisik dan mental dalam hal mengemukakan penalaran (alasan), menemukan kaitan yang satu dengan yang lain, mengomunikasikan ide/gagasan, mengemukakan bentuk representasi yang tepat, dan menggunakan semua itu untuk memecahkan masalah.

Hal yang paling utama yang menjadi keaktifan siswa di dalam kelas adalah munculnya rasa ingin tahu, ketertarikan dan minat siswa terhadap hal yang sedang dipelajari. Untuk itu, melalui berbagai teknik dan metode, guru harus berusaha sebisa mungkin untuk menciptakan suasana sedemikian rupa guna memicu rasa penasaran siswa aktif bertanya dan mempertanyakan mengemukakan gagasan. 
Peran aktif siswa dalam pembelajaran sangatlah penting. Karena pada hakikatnya, pembelajaran merupakan suatu proses aktif dari pembelajar (siswa) dalam membangun pemikiran dan pengetahuannya. Peran aktif siswa dalam pembelajaran ini akan menjadi dasar pembentukan generasi kreatif dan berkemampuan untuk menghasilkan sesuatu yang tidak hanya bermanfaat bagi dirinya sendiri, tetapi juga bagi orang lain.

\section{Pembelajaran Inovatif}

Pembelajaran inovatif dapat dilakukan dengan cara mengadaptasi model-model pembelajaran menyenangkan yang bisa membuat siswa terbebas dari kejenuhan-kejenuhan pembelajaran. Melalui model pembelajaran inovatif, peserta didik harus terbebas dari perasaan bosan, malas, ketakutan akan kegagalan atau perasaan tertekan dikarenakan tenggang waktu tugas dan lain-lain.

Banyak sekali inovasi-inovasi dalam pembelajaran yang dapat diterapkan. Misalnya saat ini tengah ramai pembelajaran dengan komputer atau lebih dikenal dengan Pembelajaran Berbasis Komputer (PBK) bermodel Drill, tutorial, atau simulasi. Materi pelajaran yang tadinya disampaikan secara lisan oleh guru, dapat dibaca sendiri oleh siswa melalui layar komputer maupun ketika diproyeksikan mealalui gambar di depan kelas.

\section{Pembelajaran Kreatif}

Pembelajaran kreatif menekankan pada pengembangan kreativitas, baik pengembangan kemampuan imajinasi dan daya cipta (mengarang, membuat kerajinan tangan, mempraktikkan kesenian, dan lain-lain) maupun pengembangan kemampuan berpikir kreatif. Pembelajaran di $\mathrm{SD} / \mathrm{MI}$ pada umumnya masih mengupayakan pengembangan kemampuan berpikir rasional logis. Dalam hal ini, guru sebagai fasilitator dituntut untuk senantiasa kreatif dalam merancang pembelajaran, serta memiliki beragam strategi pembelajaran yang digunakan agar pembelajaran tersebut memenuhi beragam tingkat kemampuan siswa di kelas. Pengetahuan siswa yang diperoleh dalam hal ini berdasarkan pengalamannya sendiri, bukan ditransfer pengetahuan dari guru.

\section{Pembelajaran Efektif}

Efektif artinya adalah berhasil mencapai tujuan sebagaimana yang diharapkan. Dengan kata lain, dalam pembelajaran telah terpenuhi apa yang menjadi tujuan dan harapan yang hendak dicapai. Aspek efektivitas pembelajaran merupakan kriteria penting dalam setiap pembelajaran. Suatu pembelajaran disebut efektif manakala pembelajaran tersebut telah mencapai tujuan pembelajaran. Tujuan yang diinginkan dalam pembelajaran itu mencakup pembentukan kemampuan, sikap, keterampilan, pengembangan kepribadian, serta kemampuan penguasaan IPTEKS (Ilmu Pengetahuan, Teknologi, dan Seni).

Dalam konteks pembelajaran di SD/MI, suatu pembelajaran dapat dinilai efektif bila pembelajaran itu telah mencapai tujuan khusus yang telah ditetapkan dalam kurikulum, yang pada dasarnya tujuan khusus tersebut telah mengacu kepada Tujuan Umum Pendidikan Nasional yang tertulis dalam Undang-Undang No. 20 Tahun 2003 tentang SISDIKNAS pasal 3:

"Pendidikan nasional berfungsi untuk mengembangkan kemampuan, dan membentuk watak serta peradaban bangsa yang bermartabat dalam rangka mencerdaskan kehidupan bangsa, bertujuan untuk mengembangkan potensi peserta didik agar menjadi manusia yang beriman dan bertakwa kepada Tuhan Yang Maha Esa, berakhlak mulia, sehat, beriman, cakap, kreatif, mandiri, dan menjadi warga negara yang demokratis dan bertanggungjawab."

\section{Pembelajaran Menyenangkan}

Pembelajaran menyenangkan merupakan pembelajaran yang didesain sedemikian rupa sehingga memberikan susana penuh keceriaan, menyenangkan, dan yang paling utama, tidak 
membosankan peserta didik. Suasana seperti itu akan membuat peserta didik bisa lebih terfokus dalam proses pembelajaran, sehingga dapat meningkatkan perhatian terhadap materi yang disampaikan oleh guru. Pembelajaran menyenangkan juga dapat dilakukan secara terpadu. Misalnya guru mengombinasikan materi pembelajaran dengan media komputerisasi yang menarik bagi siswa, sehingga peserta didik dapat memperoleh lebih dari satu pengetahuan secara sekaligus.

\section{Prinsip-prinsip PAIKEM dalam Pembelajaran}

Berikut ini dikemukakan prinsip-prinsip pembelajaran PAIKEM, yaitu:

\section{Mengalami}

Peserta didik terlibat secara aktif baik fisik, mental maupun emosional. Melalui pengalaman langsung pembelajaran akan lebih memberi makna kepada siswa daripada hanya mendengarkan. Misalnya pada mata pelajaran tertentu guru mengajarkan pembelajaran melalui media komputerisasi hingga memberikan pemahaman yang mendalam bagi siswa.

\section{Komunikasi}

Kegiatan pembelajaran memungkinkan terjadinya komunikasi antara guru dan peserta didik. Proses komunikasi yang baik adalah proses komunikasi di mana antara unsur komunikator dan komunikan terdapat satu arah yang sama.

\section{Interaksi}

Kegiatan pembelajaran memungkinkan terjadinya interaksi multiarah. Interaksi multi arah yang diharapkan terjadi adalah interaksi transaksional, di mana proses komunikasi antara guru dengan siswa, siswa antara guru, siswa dengan siswa, bahkan siswa dengan lingkungan sekitar memiliki kesiapan yang cukup baik.

\section{Refleksi}

Kegiatan pembelajaran memungkinkan peserta didik memikirkan kembali apa yang telah dilakukan. Proses refleksi sangat perlu dilakukan untuk mengetahui sejauh mana ketercapaian proses pembelajaran. Kegiatan refleksi ini dilakukan secara bersama antara guru dengan siswa.

\section{HASIL DAN PEMBAHASAN}

Kegiatan pengabdian kepada masyarakat yang dilaksanakan di SD Negeri 023 Samarinda Utara, Kecamatan Samarinda Utara, Kota Samarinda ini dilakukan melalui dua tahapan yaitu, persiapan dan pelaksanaan program inti. Tahapan-tahapan persiapan meliputi beberapa tahap yang saling berhubungan langsung di antaranya:

\section{Tahap Persiapan Pertama}

Tinjauan masyarakat sasaran kegiatan sosialisasi sebagai tahap pertama atau persiapan. Kegiatan ini bertujuan untuk mengetahui keadaan terakhir dan kondisi SD Negeri 023 Samarinda Utara, Kecamatan Samarinda Utara. Kegiatan ini dilakukan dengan melakukan kunjungan ke lokasi pengabdian masyarakat dengan melihat langsung keadaan di sana.

\section{Tahap Persiapan Kedua}

Melaksanakan koordinasi dengan pihak sekolah setelah mengetahui gambaran peserta didik. Selanjutnya dilakukan rencana strategi yang terkait pelaksanaan kegiatan pengabdian masyarakat. Kegiatan ini dilakukan dengan berkoordinasi antara tim pengabdian kepada pihak sekolah dan peserta didik yang ada di SD Negeri 023 Samarinda Utara, Kecamatan Samarinda Utara terkait dalam rangka mendapatkan arahan yang lebih baik dalam pelaksanaan sosialisasi.

\section{Tahap Persiapan Ketiga}

Kegiatan dilanjutkan dengan pembuatan kesepahaman antara pelaksana dengan sekolah sasaran. Dalam hal ini yang dilakukan adalah penjelasan mengenai kegiatan sosialisasi dan kegiatan yang dilaksanakan kepada sekolah sasaran. Hal ini dilakukan sebagai bentuk 
komunikasi antara pelaksana dengan sekolah sasaran sehingga dalam pelaksanaan sosialisasi dapat berjalan dengan baik. Komunikasi dan koordinasi ini dilakukan untuk mendapatkan gambaran mengenai waktu yang tepat dalam kegiatan sosialisasi yang dilakukan dengan mempertimbangkan saran-saran dan rekomendasi dari sekolah sasaran.

\section{Tahap Persiapan Keempat}

Penyusunan materi kegiatan sosialisasi dilakukan untuk sekolah sasaran. Pelaksana yang telah mendapatkan saran dan arahan dari sekolah sasaran terkait jadwal kegiatan di SD Negeri 023 Samarinda Utara, Kecamatan Samarinda Utara, kemudian menyusun jadwal dan materi kegiatan sosialisasi. Penyusunan kegiatan ini dilakukan dengan mempertimbangkan rekomendasi sekolah sasaran. Hal ini dilakukan agar terjadi kesepahaman serta kelancaran dalam proses pelaksanaan kegiatan sosialisasi.

\section{Tahap Persiapan Kelima}

Persiapan alat dan bahan yang dibutuhkan selama pelaksanaan kegiatan sosialisasi. Alat dan bahan yang telah diperoleh kemudian dijadikan sebagai media penunjang dalam pelaksanaan kegiatan sosialisasi. Setelah melalui tahapan persiapan yang matang. Selanjutnya memasuki tahapan program inti. Tahapan program inti ini dilakukan mengingat pentingnya pengabdian masyarakat ini dijalankan secara terstruktur dan sitematis. Adapun tahapan program inti dibagi dalam beberapa tahap di antaranya:

\section{Tahapan Program Inti Pertama}

Tahapan program inti pertama ini yaitu melakukan sosialisasi tentang pengenalan kegiatan pengabdian masyarakat kepada sekolah sasaran. Kegiatan sosialisasi ini dilakukan di SD Negeri 023 Samarinda Utara, Kecamatan Samarinda Utara warga dengan memberikan gambaran dan penjelasan mengenai kegiatan praktik langsung di kelas yang ditujukan kepada peserta didik. Tujuannya untuk mengenalkan media komputerisasi dan pembelajaran yang aktif, inovatif, efektif, dan menyenangkan (PAIKEM).

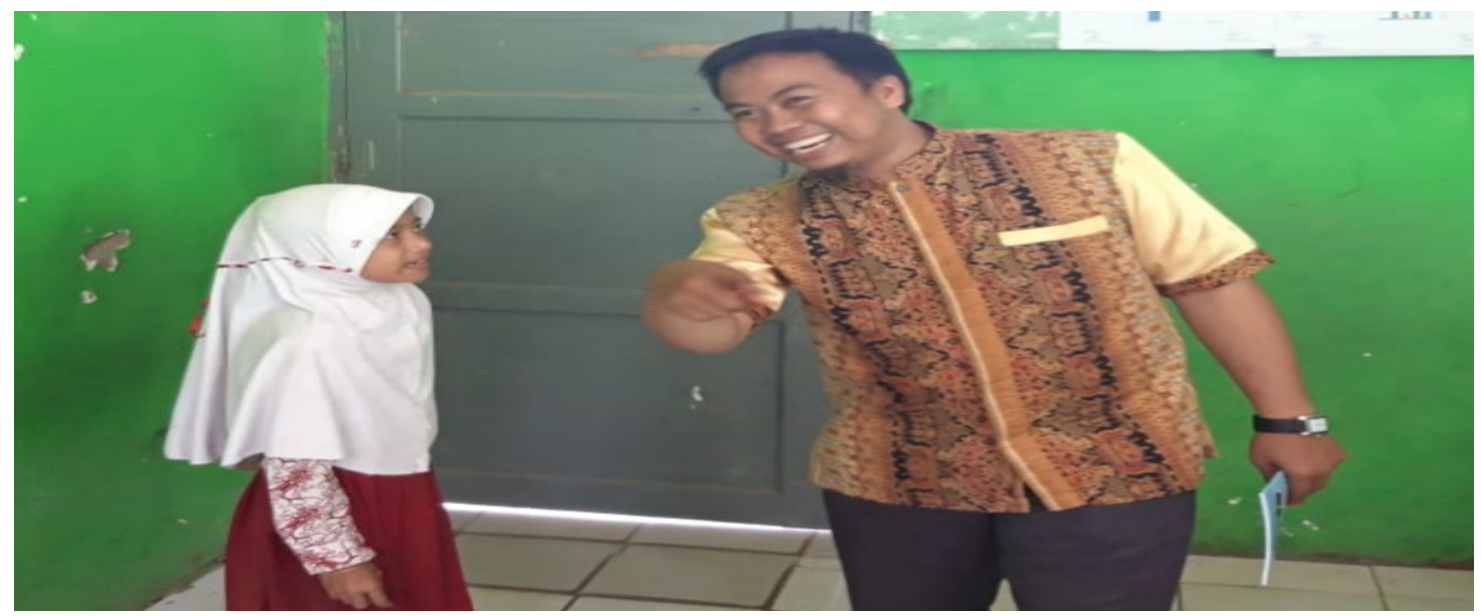

Gambar 1: Meminta salah satu siswa untuk memberikan pemahaman dasar mengenai apa yang ia telah ketahui mengenai media komputerisasi).

\section{Tahap Program Inti Kedua}

Kegiatan program inti kedua ini adalah memberi pemahaman tentang pemanfaatan media komputerisasi dan pembelajaran yang aktif, inovatif, efektif, dan menyenangkan (PAIKEM) di SD Negeri 023 Samarinda Utara, Kecamatan Samarinda Utara. Hal ini sebagai upaya langsung dalam memberikan pemahaman dengan cara melakukan praktik langsung di dalam kelas. Selanjutnya siswa diminta pendapat dan masukannya mengenai pemahaman 
mereka. Kemudian siswa dikenalkan berbagai macam cara pembelajaran yang aktif, inovatif, efektif, dan menyenangkan (PAIKEM).

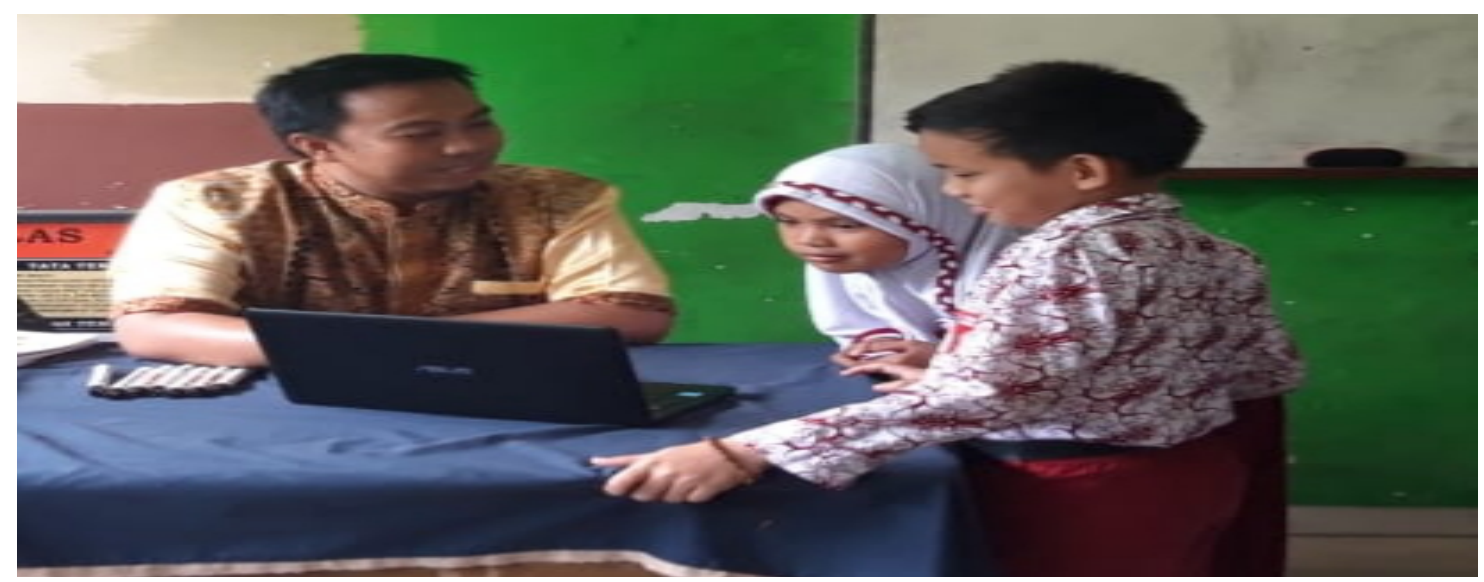

Gambar 2: Memberikan kesempatan secara langsung kepada beberapa siswa yang memerlukan penjelasan lebih mendalam.

\section{KESIMPULAN}

Adapun yang dapat kami ambil sebagai kesimpulan pada pengabdian masyarakat adalah

1. Media komputerisasi dapat menjadi alternatif dalam menerapkan pembelajaran yang aktif, inovatif, efektif, dan menyenangkan (PAIKEM) di sekolah.

2. Kegiatan pembelajaran di kelas juga dapat lebih menarik jika terjadi penggabungan antara media komputerisasi dengan pembelajaran yang aktif, inovatif, efektif, dan menyenangkan (PAIKEM) di sekolah.

3. Memberikan kesadaran kepada semua pihak pentingnya menerapkan penggabungan antara media komputerisasi dengan pembelajaran yang aktif, inovatif, efektif, dan menyenangkan (PAIKEM) di sekolah.

\section{Daftar Pustaka}

Anwar, M. (2015). Filsafat Pendidikan. Jakarta: Kencana.

Ahmadi, R. (2014). Pengantar Pendidikan (Asas \& Filsafat Pendidikan). Yogyakarta: ArRuzz Media.

Kompri. (2015). Motivasi Pembelajaran Perspektif Guru Dan Siswa. Bandung: Remaja Rosdakarya.

Kurniawan, D. (2017). Pembelajaran Terpadu Tematik (Teori, Praktik, Dan Penilaian). Bandung: Alfbeta.

Subakti, Hani dan Eka Silvi Handayani. (2021). Pengaruh Bimbingan Belajar terhadap Hasil Belajar Bahasa Indonesia Siswa Kelas Tinggi di Sekolah Dasar. Jurnal Basicedu, Vol. 5, No. 1, 2021. Halaman 247-255 https://doi.org/10.31004/basicedu .v5il.648.

Subakti, Hani dan Kiftian Hady Prasetya. (2020). Pengaruh Pemberian Reward and Punishment Terhadap Motivasi Belajar Bahasa Indonesia Siswa Kelas Tinggi di Sekolah 
Dasar. Vol.3, No.2, Desember 2020. Halaman 106-117, https://doi.org/10.36277/basataka .v3i2.93.

Subakti, Hani. (2019). 8 Konsepsi Landasan Bahasa Indonesia di Perguruan Tinggi. Parepare: Kaaffah Learning Center.

Susanto, A. (2016). Teori Belajar Dan Pembelajaran Di Sekolah Dasar. Jakarta: Kencana.

Thobroni, M. (2015). Belajar \& Pembelajaran (Teori dan Praktik). Yogyakarta: Ar-Ruzz Media.

Yaumi, M. (2014). Pendidikan Karakter Landasan, Pilar \& Implementasi.Jakarta: Kencana.

\section{Profil Penulis:}

Hani Subakti, Kelahiran Kota Samarinda, 19 Januari 1989.
Penulis merupakan staf pengajar di Program Studi
Pendidikan Guru Sekolah Dasar, Fakultas Keguruan dan
Ilmu Pendidikan, Universitas Widya Gama Mahakam
Samarinda. Penulis berfokus pada bidang kebahasaan,
pengajaran, dan kesusastraan.
Posel: hanisubakti@uwgm.ac.id

